\title{
Dual Effect of Sacral and Lower Limb Neuromodulation in Urge Incontinence
}

\author{
${ }^{1}$ Marwa M. Eid MD; ${ }^{2}$ Basant M. Elnady, MD ; ${ }^{3}$ Fatma M. Abdel Aty MD; ${ }^{4}$ Dalia Desouky \\ MD . \\ Lecturer of Surgery ${ }^{1}$ Physiotherapy faculty of physiotherapy Cairo university, lecturer of Rheumatology \\ and Rehabilitation ${ }^{2}$ faculty of medicine Benha university, lecturer of Pediatric ${ }^{3}$ Physiotherapy faculty of \\ physiotherapy Cairo university, and lecturer of Public Health and community medicine ${ }^{4}$ faculty of \\ medicine Menoufiya university,Egypt.
}

\begin{abstract}
Purpose: To investigate the effect of posterior tibial nerve electrical stimulation (PTN) and sacral surface therapeutic electrical stimulation (SSTES) in the treatment of overactive bladder.

Patient and method: Sixty patients were included in this study. Their ages ranged from 14-62 years. They were divided into two equal groups.

Procedures: Group(A)received 12weeks of treatment with sacral surface electrode and posterior tibial nerve electrical 15 min three times /week for12 weeks while group (B)received pelvic floor exercises for 15 minutes 3times/week for 12 weeks.

Results: this study revealed that the bladder volume at first desire to void for group (A)as well as for group(B); showed no statistical significant difference, bladder stability in (A)group showed a highly statistical significant improvement with a percentage $48.69 \%$ while for group(B) non significant and by comparing both groups post-treatment, there was a statistical significant difference between groups with high percentage of improvement of the bladder stability in group(A) more than group(B). Maximum flow rate was significantly improved post-treatment, for group (A) with a percentage of improvement $25.2 \%$ while, for group (B)it was with a percentage of improvement $12.37 \%$, and by comparing both groups posttreatment there was a statistical significant improvement in group(A) more than in group (B).
\end{abstract}

Conclusion PTN and sacral surface therapeutic electrical stimulation (SSTES) produced objective improvements include urodynamic changes specially bladder stability, and maximum flow rate.

Keywords: Urge incontinence, Neuromodulation, Dual, sacral, lower limb.

\section{Introduction}

Overactive bladder symptoms (urgency, frequency, nocturia and urge incontinence) are frequent complaints of patients attending urology and gynecology clinics. In many patients, the cause for these is idiopathic with no obvious underlying neurological abnormality. Patients with overactive bladder also suffer from sleep disturbance, psychological distress from embarrassment due to incontinence and disruption to social and work life. Quality of life scores (QOL) are consistently reduced in this group of patients (Tomonori,2008). 
The technology of peripheral neuromodulation is still in the relatively early stages of development. Most research in the field has been reported in the last few years with little long-term data available. The bulk of the published studies have been uncontrolled case series. A wide variety of patient populations have been studied, and the inclusion and exclusion criteria used have been variable, as have been both the metrics used to measure responses and the parameters to establish success. Published studies have reported wide variation in degrees of success. The need exists for more randomized, controlled trials as well as data on longer term outcomes (Cooperberg and Stoller ,2005).

Neuromodulation has been reported to be effective for the treatment of stress and urgency urinary incontinence. The cure and improvement rates of pelvic floor neuromodulation in urinary incontinence are $30-50 \%$ and $60-90 \%$, respectively, pelvic floor exercise with adjunctive neuromodulation is the mainstay of conservative management for the treatment of stress incontinence. For urgency and mixed stress plus urgency incontinence, neuromodulation may therefore be the treatment of choice as an alternative to drug therapy it can offer improvement in patient quality of life $(\operatorname{Corcos}$ et al., 2006).

sacral surface therapeutic electrical stimulation (SSTES) as a therapy for urinary incontinence using neuromodulation. In this therapy, skin surface electrodes are applied on the sacral surface to provide stimulation, making the treatment very easy to perform. It has been shown that SSTES has not only an inhibitory effect on detrusor overactivity but also an efferent stimulant effect to the pudendal nerve (Yokozuka et al,2004).

The tibial nerve contains fibers originating from the spinal roots L4-S3. From this site, the somatic and autonomic nerve fibers arise to supply to the pelvic floor. It is believed that through this crossover tibial nerve stimulation works. Transcutaneous stimulation progressed to percutaneous stimulation and is known as posterior tibial nerve stimulation (PTNS) was initially known as Stoller afferent nerve stimulation.Posterior tibial nerve stimulation look to be an easy and less expensive way to reach satisfactory results(Patricia et al .,2009),(Van et al., 2006) .

PTNS is a minimally invasive neuromodulation system designed to deliver retrograde electrical stimulation to the sacral nerve plexus through percutaneous electrical stimulation of the posterior tibial nerve. The posterior tibial nerve contains mixed sensory motor nerve fibers that originate from L4 through S3, which modulate the innervation to the bladder, urinary sphincter, and pelvic floor. The specific mechanism of action of neuromodulation is unclear, although theories include improved blood flow and change in neurochemical balance along the neurons. Neuromodulation may have a direct effect on the detrusor or a central effect on the micturition centers of the brain.(Patricia et al .,2009, Van et al., 2006, Sibel et al., 2008) . 


\section{Patients and Methods}

This study included sixty volunteers, who had overactive bladder (urge incontinence) they were randomly selected from the department of urodynamics of the "The National Institute of Urology and Nephrology". Their ages were ranged from 14 to 62 years old, from both sexes, all patients were free from any significant medical or pathological diseases, which may interfere with the results of the study, e.g. diabetes mellitus, cerebro-vascular stroke, active rectal lesions or infections, and neurologically free. All patients undergone a physical examination and a complete history had be taken, including previous urological symptoms as frequency, urgency, nocturnal, or incontinence. The physical examination included neurological assessment of perianal sensation, anal sphincter tone, and a brief screening for any neurological factors as, Parkinson's disease, multiples sclerosis, stroke or previous operations (mainly pelvic surgeries). Detailed analysis of the present overactive bladder symptoms had been carried. Medical history including drugs in actual use especially diuretics, and anti-diabetic drugs had been considered. Urologic examination had been carried by the staff of urology department of the National Institute of Urology and Nephrology, to exclude any genitourinary infection that might cause urinary incontinence. laboratory investigations, mainly fasting and postprandial blood glucose, complete urine analysis had been carried out to exclude diabetes mellitus, urinary tract infection as well as renal infection.
Urodynamic studies had been carried by the staff of urodynamic unit, to confirm the diagnosis of overactive bladder and urgency.

The patients were randomly divided into two equal groups; each group included thirty patients. Group(A) included thirty patients suffer from overactive bladder (urge incontinence) ,they received posterior tibial nerve electrical stimulation of faradic type, biphasic continuous rectangular, with frequency of $0-10 \mathrm{~Hz}$. plus superficial parasacral electrical stimulation .Surface electrodes were placed at the posterior sacral foramens of S2 and S4with frequency of $20 \mathrm{~Hz}$. Using the maximum tolerable intensity for 15 minutes daily for three days weekly, up to 12 weeks .Group (B) included thirty patients who received the routine physical therapy program of exercise to the pelvic floor muscle through pelvic floor exercises $15 \mathrm{~min}$ three time a week for 12 weeks.

Electrical stimulation had been delivered to the posterior tibial nerve via a combination of electrode and generator components, including a small 34-gauge needle electrode, surface electrode, lead wires and hand held electrical generator. The low-voltage stimulator (9 volts) had an adjustable pulse intensity according to patient tolerance, a fixed pulse width of 200 microseconds and a frequency of $10 \mathrm{~Hz}$. The device produces an adjustable electrical impulse that travels to the sacral nerve plexus via the tibial nerve.

Urodynamic investigation system had been used to perform the urodynamic 
investigations, as voiding cystometry .It is comprised of a trolley-mounted unit with integral printer and monitor, a mobile patient unit with built in $\mathrm{H} 2 \mathrm{O}$ and $\mathrm{CO} 2$ pumps, a stand-mounted uroflow transducer and a stand-mounted puller mechanism. Measurement had been done by the staff of the urodynamic. All patients had been subjected to multichannel cystometry before starting the study and at the end of the study (after 12 weeks).

The Measurement was done by Urodynamic Evaluation System. This procedure was performed by using the DANTIC UD5000/500 urodynamic investigation system. The urodynamic studies are valid and reliable, by testing the multichannel cystometry.

\section{The variables measured was}

- First desire to void which reveals bladder sensation.

- Bladder stability (number of uninhibited detrusor contractility).

- Maximum flow rate.

\section{Results}

Results of 1st desire to void through PTN and SSTES Electrical stimulation group (Group A) and (Group B):

As observed in table (1) and figure (1), in (Group A) the mean value of 1st desire to void before initiation of treatment (Pre) was $147.07 \pm 36.162$. While the mean value of $1 \mathrm{st}$ desire to void after application of treatment (Post) of Electrical stimulation group was $159.77 \pm 38.425$, the statistical analysis of the mean differences of 1st desire to void before and after application of treatment in Electrical stimulation group revealed no statistical significant difference $(\mathrm{P}>0.05)$ in 1 st desire to void with a percentage of improvement of $8.64 \%$ after application of treatment with Electrical stimulation.

Regarding (Group B) the mean value of 1st desire to void before initiation of treatment (Pre) was 132.6 \pm 27.677 .While the mean value of 1st desire to void after application of treatment (Post) of exercise group was 139.77 \pm 28.74 .

There was no statistical significant difference $(\mathrm{P}>0.05)$ in 1st desire to void, before and after application of treatment of Exercise group with a percentage of improvement of $0.88 \%$ after application of treatment.

Table (1): The statistical analysis of mean differences of 1 st desire to void before initiation of treatment (Pre) and after application of treatment (Post) of Electrical stimulation group (Group A) and (Group B).

\begin{tabular}{|c|c|c|c|c|}
\hline & \multicolumn{4}{|c|}{ First desire to void } \\
\hline \multirow{2}{*}{ Statistics } & \multicolumn{2}{|c|}{ Group A } & \multicolumn{2}{|c|}{ Group B } \\
\hline & Pre & Post & Pre & Post \\
\hline Mean & 147.07 & 159.77 & 132.6 & 139.77 \\
\hline $\begin{array}{l}\text { Standard } \\
\text { Deviation }\end{array}$ & 36.162 & 38.425 & 27.677 & 28.74 \\
\hline $\begin{array}{l}\text { Mean } \\
\text { Difference }\end{array}$ & \multicolumn{2}{|c|}{12.7} & \multicolumn{2}{|c|}{1.167} \\
\hline $\begin{array}{l}\text { Paired t- } \\
\text { value }\end{array}$ & \multicolumn{2}{|c|}{1.397} & \multicolumn{2}{|c|}{0.61} \\
\hline $\begin{array}{l}\text { Probability } \\
\text { value }\end{array}$ & \multicolumn{2}{|c|}{0.1731} & \multicolumn{2}{|c|}{0.546} \\
\hline Significance & \multicolumn{2}{|c|}{ Non Significant } & \multicolumn{2}{|c|}{ Non Significant } \\
\hline $\begin{array}{l}\text { Percent of } \\
\text { Change }\end{array}$ & \multicolumn{2}{|c|}{$8.64 \%$} & \multicolumn{2}{|c|}{$0.88 \%$} \\
\hline
\end{tabular}

Pre: Before treatment. Post: After 12 weeks of treatment. 


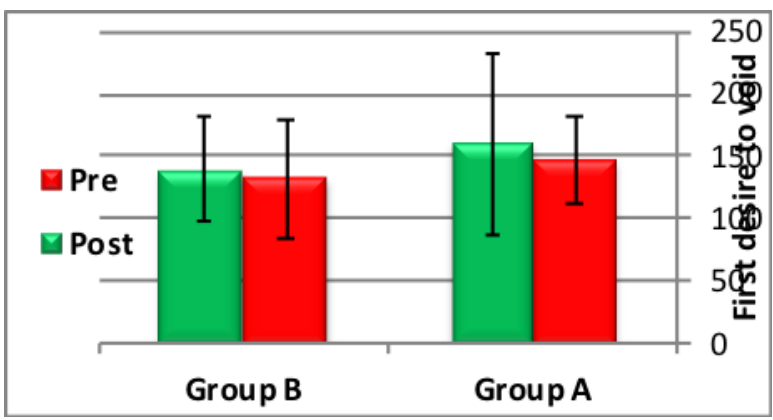

Fig.(1)Results of 1st desire to void through electrical stimulation group (Group A) and (Group B).

\section{Comparative Analysis of Testing First Desire to void between Groups of the Study:}

As observed in table (2) and figure (2), the 1st desire to void at pre-treatment and post-treatment (Group A) and (Group B) revealed no statistical significant differences ( $p>0.05)$ of mean value of 1st desire to void among both groups at entry and end of the study.

Table (2): Comparative analysis of the mean value of 1st desire to void among (Group A) and (Group B) at entry of the study and after application of treatment.

\begin{tabular}{|c|c|c|c|c|}
\hline \multirow[t]{2}{*}{ Statistics } & \multicolumn{2}{|c|}{$\begin{array}{l}\text { First desire to void at pre- } \\
\text { treatment }\end{array}$} & \multicolumn{2}{|c|}{$\begin{array}{l}\text { First desire to void after } \\
\text { application of treatment }\end{array}$} \\
\hline & Group A & Group B & Group A & Group B \\
\hline Mean & 147.07 & 132.6 & 159.77 & 139.77 \\
\hline $\begin{array}{l}\text { Standard } \\
\text { Deviation }\end{array}$ & 36.162 & 27.677 & 38.425 & 28.74 \\
\hline $\begin{array}{r}\text { Un-Paired t- } \\
\text { value }\end{array}$ & \multicolumn{2}{|c|}{0.91} & \multicolumn{2}{|c|}{1.93} \\
\hline $\begin{array}{r}\text { Probability } \\
\text { value }\end{array}$ & \multicolumn{2}{|c|}{0.364} & \multicolumn{2}{|c|}{0.058} \\
\hline Significance & \multicolumn{2}{|c|}{ Non Significant } & \multicolumn{2}{|c|}{ Non Significant } \\
\hline
\end{tabular}

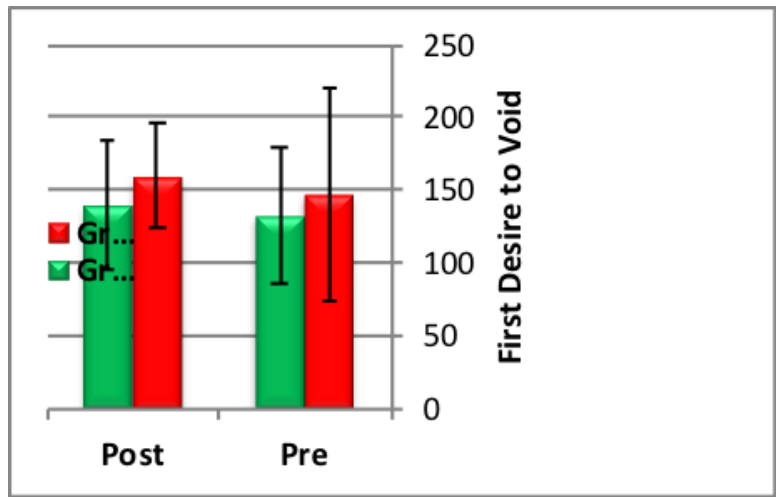

Fig. (2): Comparative analysis of the mean value of 1st desire to void among (Group A) and (Group B) at entry and after application of treatment. 


\section{Results of Stability:}

\section{Results of stability through Electrical stimulation group (Group A):}

As observed in table (3) and figure (3), the mean value of stability pre-treatment was $1.33 \pm 0.266$, with maximum value of 2 and minimum value of 1 . While the mean value of stability post-treatment of Electrical stimulation group was $1.943 \pm 0.254$, with maximum and minimum values of 2 and 1 respectively

There was a highly statistical significant difference $(\mathrm{P}<0.05)$ in stability, post-treatment with electrical stimulation group when compared with the corresponding mean value before initiation of treatment, with a percentage of improvement of $48.69 \%$.

\section{Results of stability through Exercise group (Group B):}

As observed in table (3) and figure (3), the mean value of stability before initiation of treatment (Pre) was $1.567 \pm 0.3$, with maximum value of 2 and minimum value of 1 . While the mean value of stability after application of treatment (Post) of exercise group was $1.733 \pm 0.29$, with maximum and minimum values of 2 and 1 respectively.

There was no statistical significant difference $(\mathrm{P}>0.05)$ in stability ,before and after application of treatment in exercise group ,with a percentage of improvement of $4.25 \%$ after application of treatment . Table (3): The statistical analysis of mean differences of stability before initiation of treatment (Pre) and after application of treatment (Post) of (Group A) and (Group B).

\begin{tabular}{|c|c|c|c|c|}
\hline \multirow{3}{*}{ Statistics } & \multicolumn{4}{|c|}{ Stability } \\
\hline & \multicolumn{2}{|c|}{ Group A } & \multicolumn{2}{|c|}{ Group B } \\
\hline & Pre & Post & Pre & Post \\
\hline Mean & 1.33 & $\begin{array}{l}1.94 \\
3\end{array}$ & 1.567 & 1.733 \\
\hline $\begin{array}{l}\text { Standard } \\
\text { Deviation }\end{array}$ & 0.266 & 0.254 & 0.3 & 0.29 \\
\hline $\begin{array}{l}\text { Mean } \\
\text { Difference }\end{array}$ & \multicolumn{2}{|c|}{0.61} & \multicolumn{2}{|c|}{0.06667} \\
\hline $\begin{array}{l}\text { Probability } \\
\text { value }\end{array}$ & \multicolumn{2}{|c|}{0.0001} & \multicolumn{2}{|c|}{0.1991} \\
\hline Significance & \multicolumn{2}{|c|}{$\begin{array}{c}\text { Highly } \\
\text { Significant }\end{array}$} & \multicolumn{2}{|c|}{ Not Significant } \\
\hline $\begin{array}{l}\text { Percent of } \\
\text { Change }\end{array}$ & \multicolumn{2}{|c|}{$48.69 \%$} & \multicolumn{2}{|c|}{$4.25 \%$} \\
\hline
\end{tabular}

Pre: Before treatment.

Post: After 12 weeks of treatment.

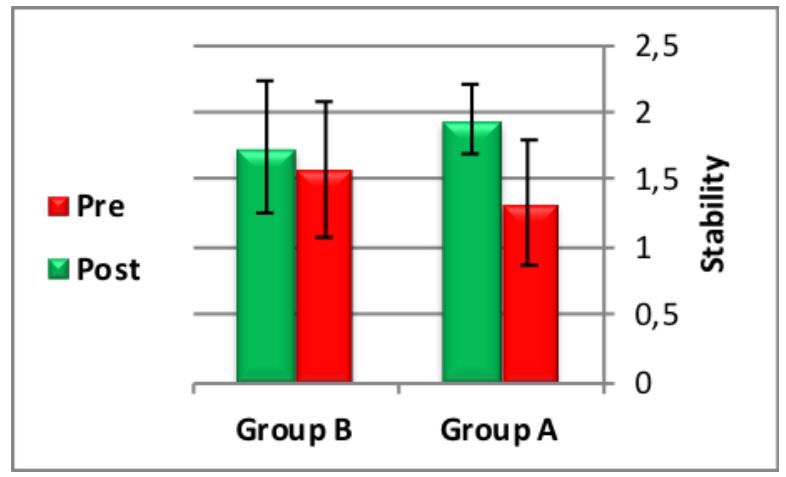

Fig. (3): Mean values of stability before and after application of treatment with Electrical stimulation group (Group A) and (Group B). 


\section{Comparative Analysis of Testing stability} between Groups of the Study:

As observed in table (4) and figure (4), the stability at pre- treatment for Electrical stimulation group (Group A) and Exercise group (Group B) revealed no statistical significant differences $(p>0.05)$ of mean value of stability among both groups at entry of the study, while at the end of the study (post) treatment, there was a statistical significant differences $(p<0.05)$ of mean value of stability among both groups.

Table (4): Comparative analysis of the mean value of stability among (Group A) and

Exercise group (Group B) before and after treatment.

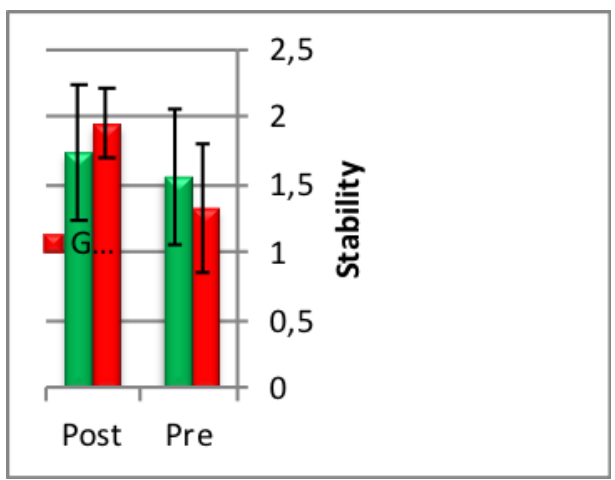

Fig. (4): The mean values of stability between (Group A) and (Group B).

Results of Maximum flow rate: Results of maximum flow rate through Electrical stimulation group (Group A) and (Group B): regarding table (5) and figure (5):

In (Group A) the mean value of maximum flow rate before initiation of treatment (Pre) was $12.51 \pm 2.263$, with maximum value of 37.4 and minimum value of 2 . While the mean value of maximum flow rate after application of treatment (Post) of Electrical stimulation group was $15.663 \pm 3.861$, with maximum and minimum values of 23 and 6.9 respectively.

There was statistical significant difference $(\mathrm{P}<0.05)$ in maximum flow rate, before and after application of treatment, with a percentage of improvement of $25.2 \%$.

In group (Group B): The mean value of maximum flow rate before initiation of treatment (Pre) was $11.397 \pm 1.883$, with maximum value of 20 and minimum value of 3.1. While the mean value of maximum flow rate after application of treatment (Post) of Exercise group was $12.807 \pm 2.693$, with

\begin{tabular}{|r|c|c|c|c|}
\hline \multirow{2}{*}{ Statistics } & \multicolumn{2}{|l|}{$\begin{array}{l}\text { Stability at pre- } \\
\text { treatment }\end{array}$} & \multicolumn{2}{c|}{$\begin{array}{c}\text { Stability after } \\
\text { application of } \\
\text { treatment }\end{array}$} \\
\cline { 2 - 5 } & $\begin{array}{c}\text { Grou } \\
\text { p A }\end{array}$ & $\begin{array}{c}\text { Group } \\
\text { B }\end{array}$ & $\begin{array}{c}\text { Group } \\
\text { A }\end{array}$ & $\begin{array}{c}\text { Group } \\
\text { B }\end{array}$ \\
\hline Mean & 1.33 & 1.567 & 1.943 & 1.733 \\
\hline $\begin{array}{r}\text { Standard } \\
\text { Deviation }\end{array}$ & 0.266 & 0.3 & 0.254 & 0.29 \\
\hline Student t test & \multicolumn{2}{|c|}{1.90} & \multicolumn{2}{|c|}{2.08} \\
\hline $\begin{array}{r}\text { Probability } \\
\text { value }\end{array}$ & \multicolumn{2}{|c|}{0.0625} & \multicolumn{2}{|c|}{0.041} \\
\hline Significance & \multicolumn{2}{|c|}{ Not Significant } & \multicolumn{2}{|c|}{ Significant } \\
\hline
\end{tabular}

maximum and minimum values of 21 and 5 respectively.

There was statistical significant difference $(\mathrm{P}<0.05)$ in maximum flow rate, before and after application of treatment (Post) of Exercise group . With a percentage of improvement of $12.37 \%$. 
Table (5): The statistical analysis of mean differences of maximum flow rate before initiation of treatment (Pre) and after application of treatment (Post) of Electrical stimulation group (Group A) and (Group B).

\begin{tabular}{|l|c|c|c|c|}
\hline \multirow{2}{*}{ Statistics } & \multicolumn{4}{|c|}{ Maximum flow rate } \\
\cline { 2 - 5 } & \multicolumn{2}{|c|}{ Group A } & \multicolumn{2}{c|}{ Group B } \\
\cline { 2 - 5 } Mean & 12.51 & 15.663 & 11.397 & 12.807 \\
\hline $\begin{array}{l}\text { Standard } \\
\text { Deviation }\end{array}$ & 2.263 & 3.861 & 1.883 & 2.693 \\
\hline $\begin{array}{l}\text { Mean } \\
\text { Difference }\end{array}$ & \multicolumn{2}{|c|}{3.153} & \multicolumn{2}{|c|}{1.41} \\
\hline $\begin{array}{l}\text { Paired t- } \\
\text { value }\end{array}$ & 3.277 & \multicolumn{2}{|c|}{2.871} \\
\hline $\begin{array}{l}\text { Probability } \\
\text { value }\end{array}$ & \multicolumn{2}{|c|}{0.0027} & \multicolumn{2}{|c|}{0.0076} \\
\hline Significance & \multicolumn{2}{|c|}{ Significant } & \multicolumn{2}{|c|}{ Significant } \\
\hline $\begin{array}{l}\text { Percent of } \\
\text { Change }\end{array}$ & \multicolumn{2}{|c|}{$25.2 \%$} & \multicolumn{2}{|c}{$12.37 \%$} \\
\hline
\end{tabular}

Pre: Before treatment. Post:

After 12 weeks of treatment.

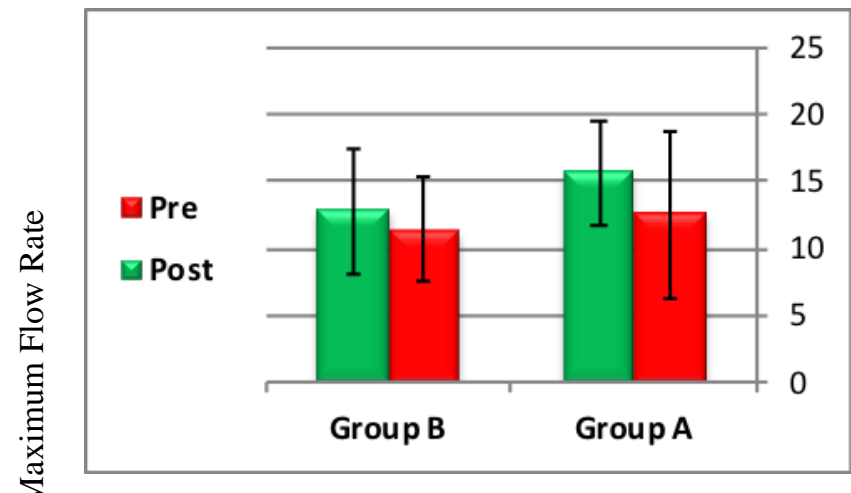

Fig. (5): Mean values of maximum flow rate before initiation of treatment (Pre) and after application of treatment (Post) between (Group A) and (Group B)

Comparative Analysis of Testing Maximum flow rate between Groups of the Study:
As observed in table (6) and figure (6), the statistical analysis of maximum flow rate before treatment for Electrical stimulation group (Group A) and Exercise group (Group B) revealed no statistical significant differences ( $p>0.05)$ of mean value of maximum flow rate among both groups.

While the maximum flow rate after application of treatment (Post) for Electrical stimulation group (Group A) and Exercise group (Group B) revealed statistical significant differences $(p<0.05)$ of mean value of maximum flow rate among both groups.

Table (6): Comparative analysis of the mean value of maximum flow rate among Electrical stimulation group (Group A) and Exercise group (Group B) before and after application of treatment.

\begin{tabular}{|c|c|c|c|c|}
\hline \multirow[t]{2}{*}{ Statistics } & \multicolumn{2}{|c|}{$\begin{array}{c}\text { Maximum flow } \\
\text { rate at pre- } \\
\text { treatment }\end{array}$} & \multicolumn{2}{|c|}{$\begin{array}{c}\text { Maximum flow } \\
\text { rate after } \\
\text { application of } \\
\text { treatment }\end{array}$} \\
\hline & $\begin{array}{c}\text { Group } \\
\text { A }\end{array}$ & $\begin{array}{c}\text { Group } \\
\text { B }\end{array}$ & $\begin{array}{c}\text { Group } \\
\text { A }\end{array}$ & $\begin{array}{c}\text { Group } \\
\text { B }\end{array}$ \\
\hline Mean & 12.51 & 11.397 & 15.663 & 12.807 \\
\hline $\begin{array}{l}\text { Standard } \\
\text { Deviation }\end{array}$ & 2.263 & 1.883 & 3.861 & 2.693 \\
\hline $\begin{array}{l}\text { Un-Paired t- } \\
\text { value }\end{array}$ & \multicolumn{2}{|c|}{0.7678} & \multicolumn{2}{|c|}{$\frac{1}{2.575}$} \\
\hline $\begin{array}{l}\text { Probability } \\
\text { value }\end{array}$ & \multicolumn{2}{|c|}{0.4457} & \multicolumn{2}{|c|}{0.0126} \\
\hline Significance & \multicolumn{2}{|c|}{ Non Significant } & \multicolumn{2}{|c|}{ Significant } \\
\hline
\end{tabular}

Pre: Before treatment.

Post:After12 weeks of treatment. 


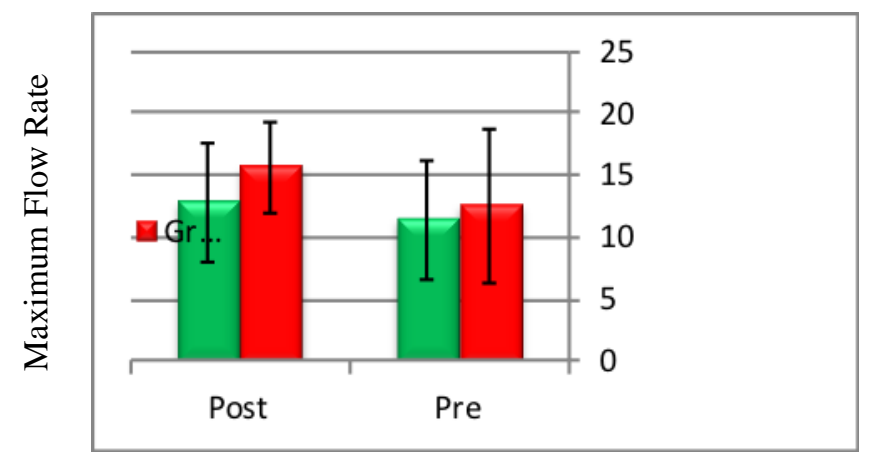

Figure (6): Comparative analysis of the mean value of maximum flow rate among (Group A) and (Group B) at entry of the study and after application of treatment.

\section{Discussion}

Overactive Bladder Syndrome (OAB) refers to individuals with the following symptoms: urinary urgency, excessive urinary frequency, or urge incontinence. These symptoms are not life threatening, but can cause embarrassment. Incontinence, the most problematic symptom, predominantly affects women and occurs in approximately one-third of those with $\mathrm{OAB}$. $\mathrm{OAB}$ is sometimes induced or exacerbated by drugs(Hay-Smith et al., 2002).

Patricia et al.(2009) noted that posterior tibial nerve electrical stimulation was chosen as the physiotheraputic method because it is an interesting alternative for the treatment of overactive bladder, which is effective and without side effects., despite the fact that pharmacological treatment is currently the first option for the treatment of women with clinical symptoms of overactive bladder, adherence to treatment is low, especially due to side effects which lead to discontinuation in $60 \%$ of cases. Posterior tibial nerve electrical stimulation is considered to be a simpler, less invasive and easy to apply form of peripheral sacral stimulation that is well tolerated by patients and more affordable(Patricia et al .,2009).

Posterior tibial nerve stimulation (PTNS) is a technique of electrical neuromodulation for the treatment of voiding dysfunction in patients who have failed behavioral and/or pharmacologic therapies. Voiding dysfunction includes urinary frequency, urgency, incontinence, and nonobstructive retention. Altering the function of the posterior tibial nerve with PTNS is believed to improve voiding function and control. While the posterior tibial nerve is located near the ankle, it is derived from the lumbar-sacral nerves (L4-S3) which control the bladder detrusor and perineal floor (Nygard, 2000).

PTNS is a minimally invasive technique that is effective to suppress detrusor over activity (Sibelet al .,2008). There was an objective effect of PTNS on urodynamic parameters (significant improvement in maximum capacity and involuntary detrusor contraction (Amarenco et al., 2003).

In our study neuromodulation using the both beneficial effect of SSTES and PTN ,Electrical stimulation offers a nondestructive alternative for patients with urge incontinence caused by over active bladder that is refractory to conservative treatment modalities. 
This supported by Peters et al.( 2010) who conducted a multicenter, double-blind, randomized, controlled trial comparing the efficacy of percutaneous tibial nerve stimulation to sham through 12 weeks of therapy. The improvement in global response assessment, voiding diary parameters, and overactive bladder and quality of life questionnaires was detected and significant improvement in bladder symptoms with $54.5 \%$ reporting moderately or markedly improved responses(Peters et al. ,2010).

PTNS produce improvement in bladder instability voiding frequency \&bladder capacity by urodynamics evidence(Klinger et al., 2000).

Capitanucci et al. (2009) evaluated the efficacy of percutaneous tibial nerve stimulation for different types of pediatric lower urinary tract dysfunction in 14 children with idiopathic overactive bladder, 14 with dysfunctional voiding, 5 with underactive bladder, 4 with underactive valve bladder and 7 with neurogenic bladder resistant to conventional therapy. Follow up data at 1 and 2 years were compared with those obtained after stimulation. The investigators found that percutaneous tibial nerve stimulation is reliable and effective for nonneurogenic, refractory lower urinary tract dysfunction in children. Efficacy seemed better in dysfunctional voiding than in overactive bladder cases(Klinger et al.,2000).

The application of PTNS could not abolish DI (detrusor instability). PTNS increased cystometric capacity and delayed the onset of
DI. Cystometry seemed useful to select good candidate's patients without DI or with late DI onset showed to be the best candidates for PTN(Van et al. ,2003).

In our results there was a highly statistical significant difference in mean value of stability in the patient treated with SSTES and PTN Electrical stimulation when compared with the value before initiation of treatment with improvement about $48.69 \%$ and no significant improvement for patient treated with pelvic floor exercise. Maximum flow rate was significantly improved post-treatment with neuromodulation with $25.2 \%$ improvement as well as for pelvic floor exercise group with a percentage of improvement $12.37 \%$, and by comparing both groups post treatment there was a statistical significant improvement in neuromodulation group more than pelvic floor group.

Objective results based on frequency volume charts, voided volume, number of leakage episodes, incontinence severity, number of pads used and quality of life was reported after application of PTNS (Nygard, 2000, Klinger et al., 2000, Gisolf et al. ,2000, Mazurick and LandisJR,2000). Also improvement in maximum flow rate, detrusor pressure at maximal flow, cystometric residual volume and bladder indices(Van et al., 2001).

In a study included10 women and five men (mean age, 60 years) with chronic pelvic pain and urinary symptoms who had failed with other therapies. After 12 weekly PTNS treatments, mean visual analogue scale score for urgency 
changed from $4.5 \pm 1.0$ at baseline to $2.7 \pm 0.7$ $(\mathrm{P}<0.05)$.Mean visual analogue score for pain decreased from $8.1 \pm 0.2$ at baseline to $4.1 \pm 0.6$ after 12 weeks of treatment $(\mathrm{P}<0.01)$. They found no statistically significant changes in the number of voids or bladder volume from baseline after treatment(Kim et al., 2007).

Patients with over active bladder symptoms (urgency ,frequency)after PTNS had a good results and urodynamics parameters were improved after treatment and proved statistically significant decrease in leakage episodes ,frequency and nocturea (Van-Blaken et al., 2004).

Of the 17 children treated with superficial sacral stimulation and biofeedback there was complete improvement of symptoms in 10, significant improvement in two and mild improvement in five. Six children who had no resolution of symptoms after biofeedback had salvage therapy with electrical stimulation, after which four had complete improvement of symptoms, and two $90 \%$ and $40 \%$ improvement, respectively. Taking the two groups together, after treatment, four children developed isolated episodes of urinary tract infection. Of 21 children with nocturnal enuresis, bed-wetting continued in 13 (62\%) after treatment (Barroso et al.,2006).

Parasacral TENS has been shown to be more effective than sham in randomized trials in treating LUTD not related to congenital abnormalities or neurological disease. This deserves further research to elucidate the optimal parameters and the children for whom it is most useful (Ubirajara et al.,2011).

Peripheral nerve stimulation produce a statistical significant improvement in lower urinary tract symptoms specially day time \&night time voiding frequency and volume,leakage episodes(Congregado et al., 2004).

\section{Conclusion}

Posterior tibial nerve electrical stimulation and SSTES is a new non invasive trend in the treatment of overactive bladder and urgency, it produced objective improvements include urodynamics changes specially bladder stability, bladder maximum cyctometric capacity and maximum flow rate.

\section{References}

1. Amarenco G, Sheikh I, Raibaut P, Kerdraon J, and (2003): Urodynamic Effect of Acute Trasncutaneous Posterior Tibial Nerve Stimulation in Overactive Bladder. J Urol, 169:2210-2215.

2. Barroso U Jr, Lordêlo P, Lopes A, Andrade J, Macedo A Jr, Ortiz V(2006): Non pharmacological treatment of lower urinary tract dysfunction using biofeedback and transcutaneous electrical stimulation; a pilot study: Paediatric Urology, Federal University of Bahia, Brazil. : 98 (1):166-71.

3. Capitanucci M L, Camanni D, Demelas F, et al, (2009): Long-term efficacy of percutaneous tibial nerve stimulation for different types of lower urinary tract dysfunction in children. J Urol, 182 (4 ): 2056-61.

4. Congregado B, Ruiz X, Pena M, Quteririno, Campoy $P$, Martinez, Leon Duenas, Leal Lopez, (2004): peripheral afferent nerve stimulation for treatment of lower urinary tract irritative symptoms. European Urology, 45:6569. 
5. Cooperberg M R, Stoller M L, (2005): Percutaneous neuromodulation. Urol Clin North Am, 32(1):71-78.

6. Gisolf K W, VanVenrooij G E, Eckardt M D, Boon T A, (2000): Analysis and reliability of data from 24 -hour frequency-volume charts in men with lower urinary tract symptoms due to benign prostatic hyperplasia. Eur Urol, 38: 4552.

7. Hay-Smith J, Herbison P, Ellis G, Moore K. (2002): Anticholinergic drugs, The Cochrane Database of Systematic Reviews. Issue 3. Art. No.: CD003781. DOI: 10.1002/14651858.CD00378.

8. Corcos J, Heritz D, Patrick A, Reid I, Schick S (2006): "Canadian Urological Association guidelines on urology incontinence Canadian Jour. of Urol. ;13(3):3127-3138.

9. Kim S W, Paick J S, Ku J H (2007): Percutaneous posterior tibial nerve stimulation in patients with chronic pelvic pain: a preliminary study. Urol Int, 78:58-62.

10. Klinger $\mathbf{H} \mathbf{C}$, Pycha A, Schmidbauer, Marberger M, (2000): Use of peripheral neuromodulation of S3 region for the treatment of detrusor over-activity: a urodynamics based study. Urology, 56:766-71.

11. Mazurick C A,Landis J R, (2000): Evaluation of repeat daily voiding measures in national interstitial cyctitis data base study. J Urol, 163: 1208-11.

12. NygardI, Holocomb R, (2000): Reproducibility of seven -day voiding diary in women with stress urinary incontinence. Int Urogynecol J Pelvic Floor Dysfunct, 11:15-7.

13. Patricia $\mathbf{O}$ B, Paulo C Rodrigues-Palma, Viviane Hermann, Cássio Riccetto, Miguel Bigozzi, Juan M Olivares (2009): Posterior tibial nerve stimulation in the management of overactive bladder: A prospective and controlled study, ACTAS UROLÓGICAS ESPAÑOLAS, 33(1): 58-63.

14. Peters K M, Carrico D J, Perez-Marrero R A, et al, (2010): Randomized trial of percutaneous tibial nerve stimulation versus Sham efficacy in the treatment of overactive bladder syndrome, results from the S U T trial. J Uro, 183 (4): 1438-43.

15. Sibel C Kabay, Mehmet Yuci \& Sahin Kabay (2008): Acute urodynamic effect of percutaneous posterior tibial nerve stimulation on neurogenic detrusor overactivity in patients with multiple sclerosis. urology, 71: 641-5.

16. Yamanishi T, Kamai T, and Yoshida K-I, (2008). Neuromodulation for the treatment of urinary incontinence. International Journal of Urology, 15: 665-672.

17. Ubirajara Barroso Jr, Rafael Tourinho, Patrícia Lordêlo, Piet Hoebeke, Janet Chase (2011): Electrical stimulation for lower urinary tract dysfunction in children: A systematic review of the literature. Neurourology and Urodynamics, 30(8):1429-1436.

18. Van-Blaken $M \quad R$, Vergunst $H$, and Bemelanans B L, (2004): "The Use of Electrical Device for The Treatment of Bladder Dysfunction : A Review of Methods" Journal of Urology, 172;846-851.

19. Van der Pal F, Van Balken M R, Heesakkers J P, et al, (2006): Percutaneous tibial nerve stimulation in the treatment of refractory overactive bladder syndrome: is maintenance treatment necessary?. B J U Int, 97(3): 547-50.

20. Van doninck M R, van BalkenE F, Agr J P, Heesakkers F M, Debruyne L M, Kiemeney \& B L Bemelmans (2004). Posterior tibial nerve stimulation in the treatmentof voiding dysfunction: urodynamic data. Neurourol Urodyn, 23: 246-251.

21. Van doninck V, van Balken $M$ R, Finazzi A E, Petta F, Micali F, Heesakkers J P, et al. (2003): Posterior tibial nerve stimulation in the treatment of idiopathic non obstructive voiding dysfunction. Urology, 61(3):567-72.

22. Van Melick $\mathbf{H} \mathbf{H}$, Gisolf $\mathbf{K}$ W, Eckhardt $M$ D,VanVenrooij G E, Boon T A (2001). One 24- hour frequency volume chart in women with objective urinary motor urge incontinence is sufficient. Urology, 58:188-92.

23. Yokozuka M, Namima T, Nakagawa H, Ichie M, and Handa Y,(2004): Effects and indications of sacral surface therapeutic electrical stimulation in refractory urinary incontinence, Clinical Rehabilitation, 18 (8): 899-907. View at Publisher. View at Google Scholar · View at Scopus. 


\section{ملخص عربى}

\section{التأثير المزدوج لتتبيه عصب القصبة الخلفي و الأعصاب العجزية كهربيا في علاج السلس البولي}

مروة محمد عيد محاضر في قسم الجر احة كلية العلاج الطبيعي جامعة القاهرة ؛ بسنت محمد النادي محاضر لأمر اض الروماتيزم

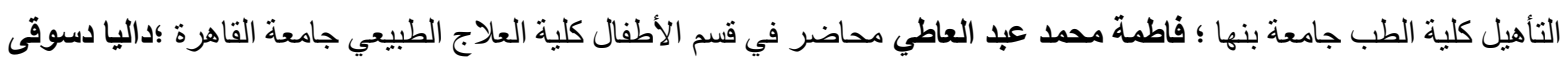

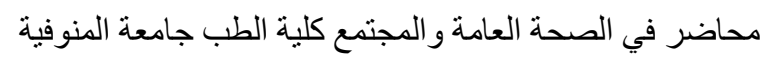

الغرض من الدراسة: هو دراسة تأثثر التنبيه الكهربي لعصب القصبة الخلفي و الاعصاب العجزية السطحية في علاج سلس البول (الإلحاحي (1)

المواد والاسباليب: قد شارك في هذه الدراسة ستون مريضا تراوحت أعمار هم بين 14-62 سنة. ونم تقسيمهم عشوائيا إلى مجموعتين. الدجموعة (أ) تلقت التنبيه الكهربائي لعصب القصبة الخلفي والاعصاب العجزية السطحية بتردد 10هيرتز ، سعة

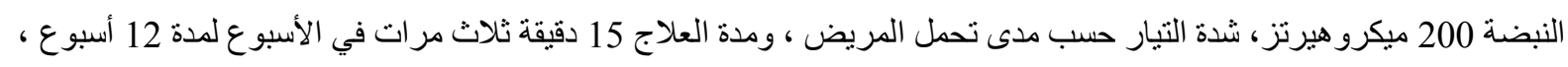

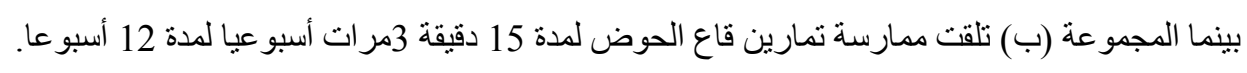

النتائج: و قد كثفت النتائج أن حجم المثانة عند الرغبة الأولى لبس لها دلالة إحصائية بالنسبة للمجموعة (أ) وكذلك بالنسبة للمجموعة (ب) ، استقر ار المثانة في المجموعة(أ) أظهرت درجة عالية ذات دلالة إحصائية مع تحسن نسبة 48.69 ٪ ، بينما بالنسبة للمجموعة (ب) لم يكن هناك فروق ذات دلالة إحصائية ، و بالمقارنة بين المجموعنين كان هنالك فروق ذات دات دلالة إحصائية بين المجموعتين و قد كانت نسبة التحسن للمجموعة (أ) 38.84 \% الحد الأقصى لمعدل التدفق تحسن بشكل ملحوظ لكلى المجمو عتين ، للمجموعة (أ) نسبة التحسن 25.2 ٪ ، وكذلك بالنسبة للمجمو عة (ب) نسبة التحسن 12.37 ٪ ، وبمقارنة المجمو عات بعد انتهاء العلاج كان هناك فروق ذائ ذات دلالة إحصائية بين المجمو عتين.

الخلاصة: وطبقا لهذه النتائج يمكن أن نستخلص أن التنبيه الكهربي لعصب القصبة الخلفي والاعصاب العجزية السطحية أدى

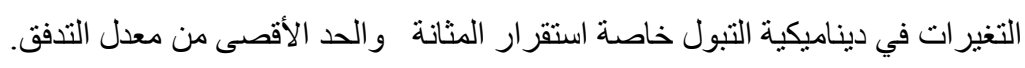

